\title{
A review on process system engineering for biodiesel refineries
}

\author{
Jharna Gupta, Madhu Agarwal *, Rajeev Kumar Dohare and Sushant Upadhyaya \\ Department of Chemical Engineering, Malaviya National Institute of Technology, Jaipur, Rajasthan, India
}

\section{(C2017 ACCENTS}

\begin{abstract}
Recently, biofuels have been focused because of environmental and society crisis including air pollution and limitation of crude oil resources. Biodiesel is known as fatty acid methyl ester which has been chosen as promising fuel because of its renewable nature and environmental benefits. The approaches for the continued growth of biodiesel process plant for development of new policies, reduction of biodiesel cost, external funding for increasing fuel cost and support for research and development of possible biodiesel feedstocks. The main purpose of this study is designing biodiesel refineries for getting maximum conversion of esters at the lowest capital cost of the refineries. Process systems engineering (PSE) approaches are ideally suited to modelling, design, optimization, and operations challenges and opportunities in the development of biodiesel plant.This review also focused on the renewability and sustainability of biodiesel production.
\end{abstract}

\section{Keywords}

Biodiesel, Refineries, Transesterification, PSE, Aspen plus.

\section{Introduction}

Fossil fuels such as coal, oil and natural gas, are currently the world's primary energy source formed from organic material. Recent production of fossil fuel has reached up to $79 \%$ compared to other energy sources as shown in Figure 1[1]. Yet fossil fuels are responsible source for the harm the environment. According to the Environmental Protection Agency (EPA), the burning of fossil fuels was responsible for $79 \%$ of U.S. greenhouse gas emissions in 2010[2-4]. Greenhouse gas emissions generated by fossil fuels can reduce with the help of Carbon Capture and Storage (CCS) technology [5]. But other, more sustainable solutions exist: energy efficiency and renewable energy which save the environment on fossil fuels as natural power source[6-9]. With the rise of global warming issues with the increase of the greenhouse gas emission and more generally with growing importance granted to renewable and sustainable development. In this regard, process system engineering (PSE) has turned to think more and more environmentally. Process systems engineering (PSE) deals with the overall system behaviour and also define that how the individual units should be combined to achieve optimal overall performance. It is a method to design and operate sustainable chemical process plant.

\footnotetext{
* Author for correspondence
}

This study will review every aspects of PSE such as process modelling, operation and control, design and synthesis, simulation, statistics and optimization that can be used in improving the processes for biodiesel production.

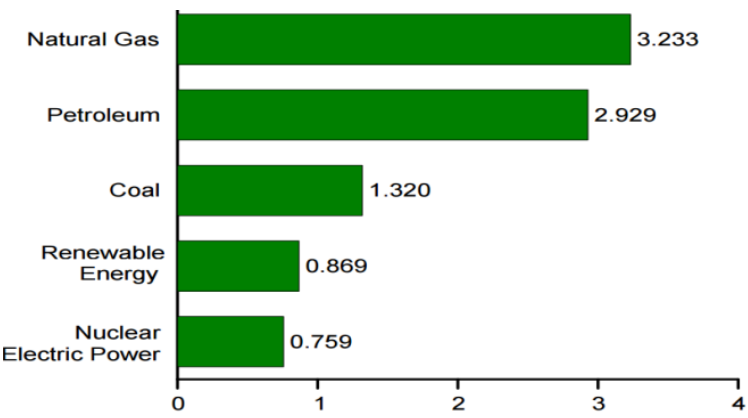

(a)

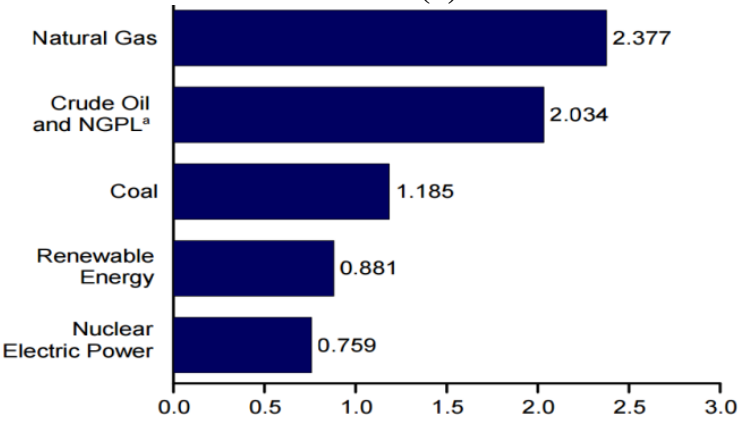

(b)

Figure 1 World primary energy (a) production and (b) consumption in January 2016, per source 


\section{Biodiesel production process}

To produce energy from low carbon sources and introduction of eco-friendly green Technology are the main aim of human society. Biodiesel, the alternative renewable liquid fuel, derived from vegetable oils holds promise to compensate the increase demand of petroleum diesel[10].Biodiesel is prepared via transesterification reaction in which triglycerides reacts with alcohol in presence of catalyst as shown in Figure 2[11].Glycerol is the by-product of the reaction. This is the most common method for producing biodiesel. The main purpose of transesterifying the vegetable oil is to lower its viscosity. Different types of feedstock like edible oils such as soybean oil, castor oil, sunflower oil, palm oil, linseed oil [12-16] and non-edible oil resources like Jatropha oil, karanja oil and thumba oil[17-19] are present in the market for biodiesel production. Transesterification reaction can be catalyzed by homogeneous and heterogeneous catalyst. Commonly homogeneous catalyst such as $\mathrm{NaOH}, \mathrm{KOH}$ have high catalytic activity but it is also difficult to separate purify and reuse them after the reaction [2021].

These drawbacks increase the economics and environmental cost in biodiesel production. So to overcome these drawbacks, heterogeneous solid catalyst such as alkali metal oxides and derivatives [22-26], alkaline earth metal oxides and derivatives, transition metal oxides and derivatives, mixed metal oxides and derivatives [27] ion exchange resins type acid heterogeneous catalyst [11], sulfated oxides as a acid heterogeneous catalyst, carbon based heterogeneous catalysts[28-30], boron group base heterogeneous catalyst waste material based heterogeneous catalysts[31-35]have been explored. Heterogeneous catalyst have many advantages as they are cheap, noncorrosive, recyclable, fast reaction rate and no need of any water purification step[36].

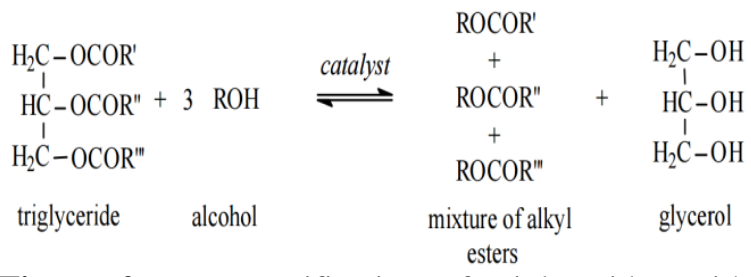

Figure 2 Transesterification of triglycerides with alcohol

\section{Process modelling and simulation}

Two possible strategies involved for the design of biodiesel are processed plant and integration. The first design tactics are selecting a reactor and moving outward by adding a separation and recycle system. This strategy is based on rules of thumb developed from the experience of the designer. Another strategy for designing biodiesel process plant is by using a process superstructure. It starts by installing all possible process options and possible interconnections as candidates for an optimal design structure. Excessive features are included to ensure that all elements that could be part of optimal solutions are incorporated.

The full design of biodiesel plant from waste cooking oil by using alkali and acid catalysts [37]. In the biodiesel production process, esterification, transesterification, methanol recovery, water washing and FAME purification were also included. Tapasvi et al. [37] performed similar research, but discrimination is the mass and energy balances in the process model. The model developed could be further applied in performing economic feasibility studies of biodiesel production. Further research on phase equilibrium systems for biodiesel production was reported in [38] to determine the liquid-liquid equilibrium of multicomponent mixtures containing fatty acid esters, alcohols and glycerol in the production and purification process. Peng-Robinson equation of state was studied in [39] to determine the methanol-triolein binary system at various temperatures and pressures.

In opposition to the studies mentioned above, Zong et al. [40] reported the use of triglycerides pure component properties for modeling the biodiesel production methods. The used method was the fragment-based strategy which comprised of constituent fragment-based modeling approach, identification of fragment-specific parameters, correlation of the parameters and estimation of double-bond effects. Subsequently Design and operation of chemical refineries by incorporating sustainability elements are currently acceptable as it promoted minimum energy usage and wastes.

For sustainable biodiesel refineries, Myint and ElHalwagi[41] had explored opportunities for cost minimization and process integration; and performed the simulation with various mass and integration processes with capital cost calculation, profitability, and sensitivity analyses. Similarly, Elms and ElHalwagi[42] also performed process design and optimization on biodiesel production process and performed capital and operating cost estimation. In short, the systematic approach to the design of 
biodiesel production processes per the GHG policies did contribute a powerful decision-making tool for policy makers and producers. Various works have been carried out on process simulation of biodiesel conversion technologies to see the effect of operating conditions towards value added products. Process simulations usually based on the evaluation of the chemical components, and selection of proper thermodynamic model.

Subsequently, unit operations, operating conditions, input conditions and plant capacity must be specified. Most of the property data of components are available in the software library. However, if the certain component property is unavailable in the simulator library, registration of the component can be made by introducing the component as a new chemical component. Garcia et al. [43] reported a simulation study to analyzed biodiesel properties using different feedstock and compared the results obtained with previous experimental data and found that the predictive model was mostly well-suited to experimental data. Zhang et al. [37] reported simulation of biodiesel plant from waste cooking oil by using alkali and acid catalysed transesterification of biodiesel.

The simulation study concluded the right amount of water could lead to near-complete separation between the FAME and glycerol phase by using pure oil in alkali transesterification process. Acid catalysed transesterification reaction conducted by Zhang et al. applied higher reaction temperature, pressure, and higher methanol to oil molar ratio than alkalicatalysed transesterification. Sotoft et al. [44] also reported similar study by using enzyme catalyst for biodiesel production. In this study, Sotoft et al. used 3 CSTRs in series with the reactors and simulation made using Aspen Plus computer simulator. The result showed the desirable yield of solvent free enzyme biodiesel production. In contrast, Kaewcharoensombat et al. [45] performed process simulations of biodiesel with or without a catalyst, purity, and type of feedstock. Although, all the simulations carried out within the specified operating conditions have proven that all process flow diagrams are able of producing high-quality biodiesel within the specified operating conditions. However, every process has some limitations such as alkali and enzyme catalysed transesterification process requires costly raw material.

On the other hand, the supercritical alcohol process requires high-pressure reactors and large amounts of energy to separate the methanol from the feed stream, thus increasing the total costs. Simulation studies are usually accompanied with production cost estimation and impact on the environment. Haas et al. [46] developed a model for estimating the cost of biodiesel production using soybean oils as feedstock. Transesterification method includes biodiesel purification and glycerol recovery sections. Capital and production costs were also estimated.

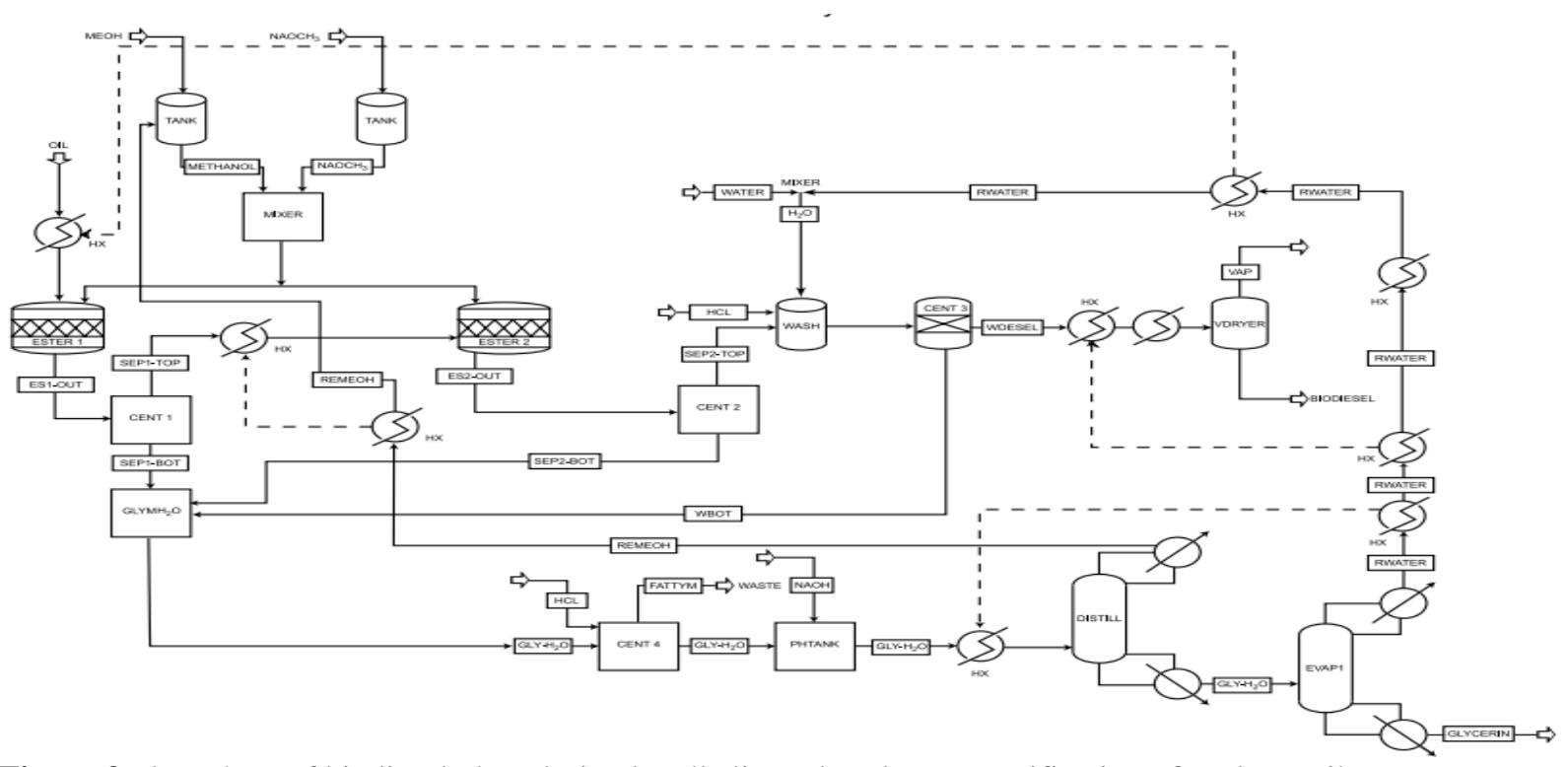

Figure 3 Flow sheet of biodiesel plant design by alkali-catalysed transesterification of soybean oil 


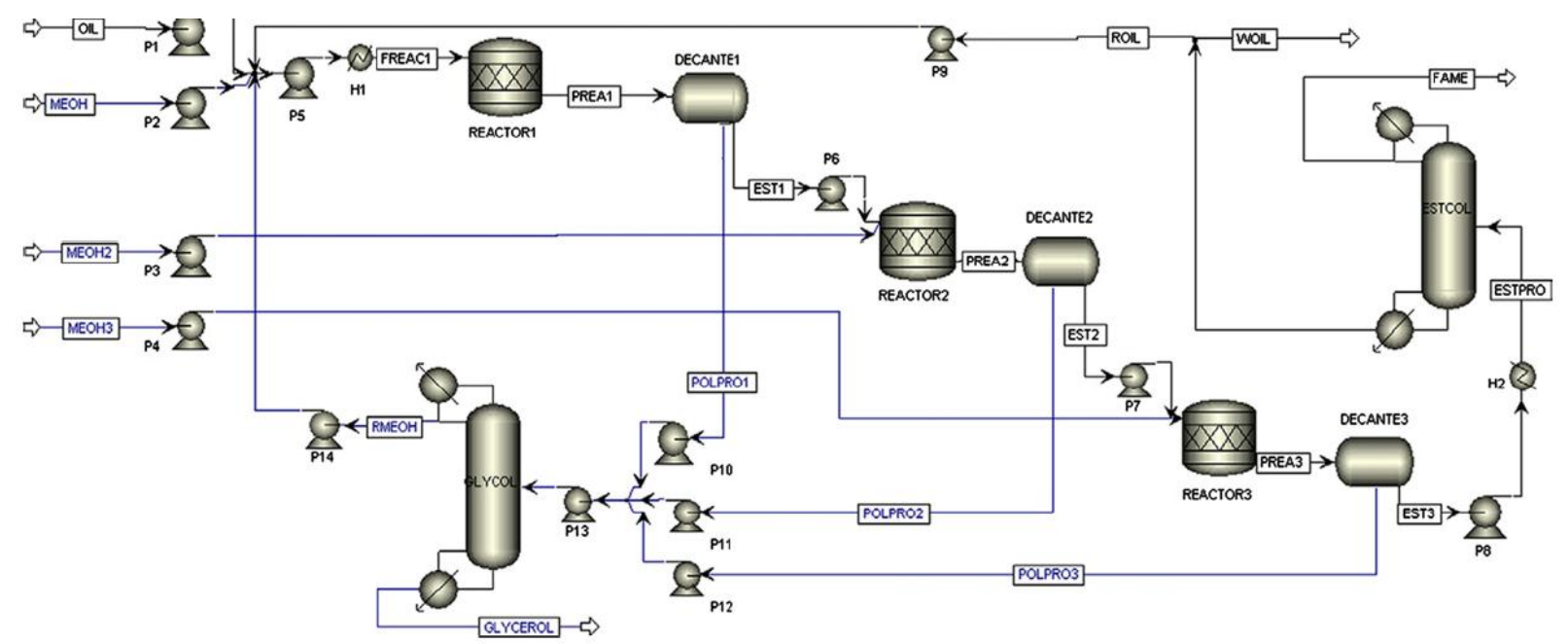

Figure 4 Flow sheet of biodiesel plant design by enzyme-catalysed transesterification of rapeseed oil

It could be concluded that the costs calculation were suitable for biodiesel derived from soybean oils, but not suitable for biodiesel from other feedstock, as additional processes may be required depending on the oil characteristics. Jegannathan et al. [47] examined the cost of biodiesel production of different types of catalysts. Costs were compared between the alkali and enzymatic-catalysed processes, which are either soluble or enzyme-immobilized. At variance to Haas et al., Jegannathan et al. also performed batch operations of biodiesel.

They discovered that the cost of alkali catalysed process was lower compared to enzymatic-catalysed process. They also suggested that, if the immobilized catalyst could be again reused, its production cost could strike the alkali catalysed production cost. Similar work was done by Sakai et al. [48] but they included research of different types of process plant refineries and manufacturing cost.

An estimation cost study of biodiesel produced in supercritical process in [49] indicated that the highest cost was incurred on raw materials and labour. If comparison of cost was made on different types of feedstock used. Figure 3-4 shows flow sheet of biodiesel plant design by alkali and enzyme-catalysed transesterification of oil.

\section{Conclusion}

Recently various studies on development of biodiesel fuel production have been reviewed and discussed. Especially in developing new more active catalysts that are capable of increasing biodiesel yield and purity with speed up the process of biodiesel production. Research should be more focused on the development of super active and strong catalysts and both esterification and transesterification reaction which helps to reduce capital and investment costs and may be advantageous for sustainable development due to the lower consumption of resources. Furthermore, flow sheeting and simulation studies in biodiesel fuel production have shown the importance of obtaining the optimum-operating conditions and verifying experimental results. The availability of powerful process simulators has enabled process engineers to cope with the complex problems of designing processes to produce the highest biodiesel purity. This review has shown that PSE is an excellent approach to systematically design and operate the complex biodiesel production system. Integrated models, methodologies and tools need to be explored through process model and design, simulation, optimization, experimentation and visualization. Therefore, the application of computer aided PSE tools for the synthesis, design, control and modeling of the biodiesel process can further advance the frontier of knowledge in this field.

\section{Acknowledgment}

None.

\section{Conflicts of interest}

The authors have no conflicts of interest to declare.

\section{References}

[1] Energy information administration. Department of Energy. US. 2016.

[2] Akbi A, Yassaa N, Boudjema R, Aliouat B. A new method for cost of renewable energy production in Algeria: Integrate all benefits drawn from fossil fuel savings. Renewable and Sustainable Energy Reviews. 2016; 56:1150-7. 
[3] Miljkovic D, Dalbec N, Zhang L. Estimating dynamics of US demand for major fossil fuels. Energy Economics. 2016; 55:284-91.

[4] Vidoza JA, Gallo WL. Projection of fossil fuels consumption in the venezuelan electricity generation industry. Energy. 2016; 104:237-49.

[5] Biresselioglu ME, Yelkenci T. Scrutinizing the causality relationships between prices, production and consumption of fossil fuels: A panel data approach. Energy. 2016; 102:44-53.

[6] Ringsmuth AK, Landsberg MJ, Hankamer B. Can photosynthesis enable a global transition from fossil fuels to solar fuels, to mitigate climate change and fuel-supply limitations? Renewable and Sustainable Energy Reviews. 2016; 62:134-63.

[7] Speirs J, McGlade C, Slade R. Uncertainty in the availability of natural resources: Fossil fuels, critical metals and biomass. Energy Policy. 2015; 87:654-64.

[8] Lightsey B. Systems engineering fundamentals. Defense Acquisition Univ Ft Belvoir Va; 2001.

[9] Agarwal M, Chauhan G, Chaurasia SP, Singh K. Study of catalytic behavior of $\mathrm{KOH}$ as homogeneous and heterogeneous catalyst for biodiesel production. Journal of the Taiwan Institute of Chemical Engineers. 2012; 43(1):89-94.

[10] Schuchardt U, Sercheli R, Vargas RM. Transesterification of vegetable oils: a review. Journal of the Brazilian Chemical Society. 1998; 9(3):199210.

[11] Al-Mulla EA, Issam AM, Al-Janabi KW. A novel method for the synthesis of biodiesel from soybean oil and urea. Comptes Rendus Chimie. 2015; 18(5):525-9.

[12] Meneghetti SM, Meneghetti MR, Wolf CR, Silva EC, Lima GE, de Lira Silva L et al. Biodiesel from castor oil: a comparison of ethanolysis versus methanolysis. Energy \& Fuels. 2006; 20(5):2262-5.

[13] Antolın G, Tinaut FV, Briceno Y, Castano V, Perez C, Ramırez AI. Optimisation of biodiesel production by sunflower oil transesterification. Bioresource Technology. 2002; 83(2):111-4.

[14] Al-Zuhair S, Ling FW, Jun LS. Proposed kinetic mechanism of the production of biodiesel from palm oil using lipase. Process Biochemistry. 2007; 42(6):951-60.

[15] Hameed BH, Lai LF, Chin LH. Production of biodiesel from palm oil (Elaeis guineensis) using heterogeneous catalyst: an optimized process. Fuel Processing Technology. 2009; 90(4):606-10.

[16] Naik M, Meher LC, Naik SN, Das LM. Production of biodiesel from high free fatty acid Karanja (Pongamia pinnata) oil. Biomass and Bioenergy. 2008; 32(4):3547.

[17] Karnwal A, Kumar N, Hasan MM, Chaudhary R, Siddiquee AN, Khan ZA. Production of biodiesel from thumba oil: optimization of process parameters. Iranica Journal of Energy \& Environment. 2010; 1(4):352-8

[18] Jairam S, Kolar P, Sharma-Shivappa R, Osborne JA, Davis JP. KI-impregnated oyster shell as a solid catalyst for soybean oil transesterification. Bioresource Technology. 2012; 104:329-35.

[19] Lee SL, Wong YC, Tan YP, Yew SY. Transesterification of palm oil to biodiesel by using waste obtuse horn shell-derived $\mathrm{CaO}$ catalyst. Energy Conversion and Management. 2015; 93:282-8.

[20] Farooq M, Ramli A, Subbarao D. Biodiesel production from waste cooking oil using bifunctional heterogeneous solid catalysts. Journal of Cleaner Production. 2013; 59:131-40.

[21] Ebiura T, Echizen T, Ishikawa A, Murai K, Baba T. Selective transesterification of triolein with methanol to methyl oleate and glycerol using alumina loaded with alkali metal salt as a solid-base catalyst. Applied Catalysis A: General. 2005; 283(1):111-6.

[22] Xie W, Peng H, Chen L. Calcined Mg-Al hydrotalcites as solid base catalysts for methanolysis of soybean oil. Journal of Molecular Catalysis A: Chemical. 2006; 246(1):24-32.

[23] Fabbri D, Bevoni V, Notari M, Rivetti F. Properties of a potential biofuel obtained from soybean oil by transmethylation with dimethyl carbonate. Fuel. 2007; 86(5):690-7.

[24] Wang L, Yang J. Transesterification of soybean oil with nano-MgO or not in supercritical and subcritical methanol. Fuel. 2007; 86(3):328-33.

[25] Arzamendi G, Campo I, Arguinarena E, Sánchez M, Montes M, Gandía LM. Synthesis of biodiesel with heterogeneous $\mathrm{NaOH} /$ alumina catalysts: comparison with homogeneous $\mathrm{NaOH}$. Chemical Engineering Journal. 2007; 134(1):123-30.

[26] Shu Q, Gao J, Nawaz Z, Liao Y, Wang D, Wang J. Synthesis of biodiesel from waste vegetable oil with large amounts of free fatty acids using a carbon-based solid acid catalyst. Applied Energy. 2010; 87(8):258996.

[27] Baroutian S, Aroua MK, Raman AA, Sulaiman NM. Potassium hydroxide catalyst supported on palm shell activated carbon for transesterification of palm oil. Fuel Processing Technology. 2010; 91(11):1378-85.

[28] Dehkhoda AM, West AH, Ellis N. Biochar based solid acid catalyst for biodiesel production. Applied Catalysis A: General. 2010; 382(2):197-204.

[29] Deka DC, Basumatary S. High quality biodiesel from yellow oleander (Thevetia peruviana) seed oil. Biomass and Bioenergy. 2011; 35(5):1797-803.

[30] Puna JF, Gomes JF, Correia MJ, Dias AS, Bordado JC. Advances on the development of novel heterogeneous catalysts for transesterification of triglycerides in biodiesel. Fuel. 2010; 89(11):3602-6.

[31] Wei Z, Xu C, Li B. Application of waste eggshell as low-cost solid catalyst for biodiesel production. Bioresource Technology. 2009; 100(11):2883-5.

[32] Viriya-Empikul N, Krasae P, Puttasawat B, Yoosuk B, Chollacoop N, Faungnawakij K. Waste shells of mollusk and egg as biodiesel production catalysts. Bioresource Technology. 2010; 101(10):3765-7.

[33] Chakraborty R, Bepari S, Banerjee A. Application of calcined waste fish (Labeo rohita) scale as low-cost 
heterogeneous catalyst for biodiesel synthesis. Bioresource Technology. 2011; 102(3):3610-8.

[34] Witoon T, Bumrungsalee S, Vathavanichkul P, Palitsakun S, Saisriyoot M, Faungnawakij K. Biodiesel production from transesterification of palm oil with methanol over $\mathrm{CaO}$ supported on bimodal meso-macroporous silica catalyst. Bioresource Technology. 2014; 156:329-34.

[35] Istadi I, Prasetyo SA, Nugroho TS. Characterization of $\mathrm{K} 2 \mathrm{O} / \mathrm{CaO}-\mathrm{ZnO}$ Catalyst for Transesterification of Soybean Oil to Biodiesel. Procedia Environmental Sciences. 2015; 23:394-9.

[36] Zhang Y, Dube MA, McLean D, Kates M. Biodiesel production from waste cooking oil: 1 . process design and technological assessment. Bioresource Technology. 2003; 89(1):1-6.

[37] Tapasvi D, Wiesenborn D, Gustafson C. Process modeling approach for evaluating the economic feasibility of biodiesel production. The Society for Engineering in Agricultural, Food and Biological Systems. 2004:1-6.

[38] Oliveira MB, Queimada AJ, Coutinho JA. Modeling of biodiesel multicomponent systems with the cubicplus-association (CPA) equation of state. Industrial \& Engineering Chemistry Research. 2009; 49(3):141927.

[39] Tang Z, Du Z, Min E, Gao L, Jiang T, Han B. Phase equilibria of methanol-triolein system at elevated temperature and pressure. Fluid Phase Equilibria. 2006; 239(1):8-11.

[40] Zong L, Ramanathan S, Chen CC. Fragment-based approach for estimating thermophysical properties of fats and vegetable oils for modeling biodiesel production processes. Industrial \& Engineering Chemistry Research. 2009; 49(2):876-86.

[41] Myint LL, El-Halwagi MM. Process analysis and optimization of biodiesel production from soybean oil. Clean Technologies and Environmental Policy. 2009; 11(3):263-76

[42] Elms RD, El-Halwagi MM. The effect of greenhouse gas policy on the design and scheduling of biodiesel plants with multiple feedstocks. Clean Technologies and Environmental Policy. 2010; 12(5):547-60.

[43] García M, Gonzalo A, Sánchez JL, Arauzo J, Peña JÁ. Prediction of normalized biodiesel properties by simulation of multiple feedstock blends. Bioresource Technology. 2010; 101(12):4431-9.

[44] Sotoft LF, Rong BG, Christensen KV, Norddahl B. Process simulation and economical evaluation of enzymatic biodiesel production plant. Bioresource Technology. 2010; 101(14):5266-74.

[45] Kaewcharoensombat U, Prommetta K, Srinophakun T. Life cycle assessment of biodiesel production from jatropha. Journal of the Taiwan Institute of Chemical Engineers. 2011; 42(3):454-62.

[46] Haas MJ, McAloon AJ, Yee WC, Foglia TA. A process model to estimate biodiesel production costs. Bioresource Technology. 2006; 97(4):671-8.
[47] Jegannathan KR, Eng-Seng C, Ravindra P. Economic assessment of biodiesel production: Comparison of alkali and biocatalyst processes. Renewable and Sustainable Energy Reviews. 2011; 15(1):745-51.

[48] Sakai T, Kawashima A, Koshikawa T. Economic assessment of batch biodiesel production processes using homogeneous and heterogeneous alkali catalysts. Bioresource Technology. 2009; 100(13):3268-76.

[49] Deshpande A, Anitescu G, Rice PA, Tavlarides LL. Supercritical biodiesel production and power cogeneration: technical and economic feasibilities. Bioresource Technology. 2010; 101(6):1834-43.

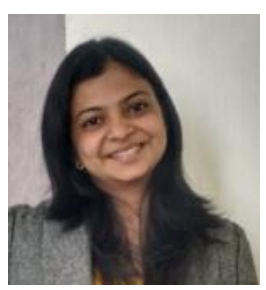

Jharna Gupta is $\mathrm{PhD}$ scholar in Department of Chemical Engineering, Malaviya National Institute of Technology (MNIT), Jaipur. She is currently working on Biodiesel Synthesis in Helical coil reactor. She is also a member of IIChE (Indian Institite Of Chemical Engineers). She is the author/co-author of over 9 scientific papers including communications in national and international conferences.

Email:2013rch9542@mnit.ac.in

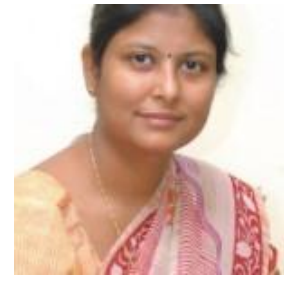

Madhu Agarwal is Assistant Professor in Department of Chemical Engineering, Malaviya National Institute of Technology (MNIT), Jaipur. She received her $\mathrm{PhD}$ in Chemical Engineering from MNIT, Jaipur. She is the author/coauthor of over 38 scientific papers with 128 citations including communications in national and international conferences. Her research interests are in the areas of biodiesel, modeling \& simulation, water treatment, adsorption.

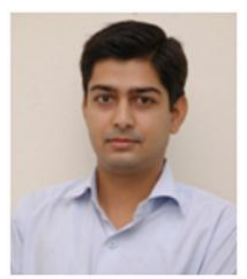

Sushant Upadhaya is Assistant Professor in Department of Chemical Engineering, Malaviya National Institute of Technology (MNIT), Jaipur. He received his $\mathrm{PhD}$ in Chemical Engineering from MNIT, Jaipur. He is the author/co-author of over 18 scientific papers with 32 citations including communications in national and international conferences. His research interests are in the areas of Mathematical Modeling, Desalination, Transport Phenomena, Advance Separation Process, Polymer Processing. 